\title{
WOT Enabled Smart Cities integrated Big Data Analytics
}

\author{
Varun Tiwari, PhD \\ Associate Professor \\ Trinity Institute of Professional \\ Studies, Dwarka
}

\author{
Vikas Rao Vadi, PhD \\ Director \\ Don Bosco Technical Training \\ Society, Okhla
}

\author{
Mukta Sharma, PhD \\ Associate Professor \& HOD \\ Trinity Institute of Professional \\ Studies, Dwarka
}

\begin{abstract}
New Modern cities fortified with Network Sensors. Sensors generate a large amount of data from various resources such as transportation, intelligent lighting, waste management, WoT enabled buildings and wot enabled healthcare, etc. In Case a user wants to analyze such large amount of data generated by the smart cities' sensors, then Big Data Analysis Tools could solve this problem. This research paper focuses on Big Data Analytics, and WOT enabled Smart Cities.

It also explains various application which used in WOT enabled Smart Cities for integration Big Data. This Paper covers Web of Things, Smart Cities, and Big Data Analysis, etc. This Paper covered Five main areas Applications such as WOT enabled Smart Cities integration with Big Data, WOT Technology, Role of WOT enabled Smart Cities Infrastructure Integration Big Data, Elements of WOT enabled Smart Cities integration Big Data, Case study WOT enabled Lighting System for Smart Cities integration Big Data.
\end{abstract}

\section{Keywords}

Web of Things, Smart Cities, Big Data, Data Integration, Big Data Analytics, Cloud.

\section{INTRODUCTION}

The world urban population is increasing rapidly and has reached approximately 5.7 billion in the year 2019. The demand and resources in cities are growing day by day. Therefore, cities need new technologies for managing public security and safety, traffic congestion, water management, smart parking, smart lighting, waste management, intelligent roads, Electromagnetic field level, and structure health. WoT is a broad network of connected devices by wire or wireless. It uses various applications like lighting, roads, traffic congestion, Vehicle or home equipment's etc. That WoT enabled devices provide the connection and exchange extensive large amount of data easily.

Big Data is large volume or amount of data sets. It has three types- structure, semi-structured and unstructured. This data is huge and complex so that difficult to managing and processing in traditional database and Database software tools. There are some characteristics of Big Data, such as:

1. Volume: It refers to a large amount of data.

2. Variety: Variety means types of data that is structured, semi-structured, and unstructured.

3. Velocity: It indicates how the data flows in from various sources. Flow depends on massive and continuous.

4. Veracity: It refers to the uncertainty of data. It means the quality and accuracy of data.

To make or design a smart city, one needs to implement and learn new technologies like cloud, Big Data Analysis, and
Web of Things. Smart cities are the concept of utilizing new technologies by connecting data sensors using wireless or wired communication to enhance and become dominant in term of infrastructure and city operation. Big Data Analytical technologies are used to monitor and manage power plants, waste management, IT devices, civic bodies, transportation systems, and other community services.

Web of Things is a distributed network on cloud that used lacs or more network devices like wire or wireless; It's sensors can be sending data from one place to another place using secure communication channel. AI, R Programming, Python, and Machine Language are capable for sending information or data from gadgets via a network and received that data from the connected gadgets. The cloud-based technologies are also used to support for adjusting, monitoring, and managing devices. Many cities which used WOT enabled devices and sensors for improving the lives of its people and help them upgrade their infrastructure.

These days the government of India is spending the right amount of money and time on such technologies. They have implemented and depicted the best use of such Technology at Kumbh Mela at prayagraj; especially for controlling the crowd at Railway station, disease surveillance, garbage trucks, washroom hygiene, etc.

MCD is also adopting new technologies to save costs. Various smart cities are converting the $4 \mathrm{G}$ network to $5 \mathrm{G}$ networks. $5 \mathrm{G}$ Technology is a more robust network for running cloudbased WOT powered devices. Such as electronic road devices, street lighting, WOT enabled traffic light, waste management devices, and smart parking devices. Countries like India, Japan, and South Korea are conducting 5G network trails.

\section{APPLICATIONS WOT ENABLED SMART CITIES INTEGRATION BIG DATA}

There are some applications enabling WOT Smart Cities [1]. It shows in table no. 1

Table 1: Applications WOT enabled Smart Cities

\begin{tabular}{|c|c|c|c|}
\hline $\begin{array}{l}\text { Application } \\
\text { Area for Smart } \\
\text { Cities }\end{array}$ & Description & $\begin{array}{l}\text { Stakehol } \\
\text { ders }\end{array}$ & Example \\
\hline $\begin{array}{l}\text { Smart Public } \\
\text { Transportation, } \\
\text { Road Traffic }\end{array}$ & $\begin{array}{l}\text { There are lots } \\
\text { of sensors } \\
\text { used for } \\
\text { public } \\
\text { transportation. } \\
\text { Such as hand } \\
\text { held counter } \\
\text { or record data } \\
\text { for Vehicle, } \\
\text { Camera }\end{array}$ & $\begin{array}{l}\text { Local } \\
\text { People, } \\
\text { authority } \\
\text { and } \\
\text { communi } \\
\text { ty. }\end{array}$ & $\begin{array}{l}\text { Traffic } \\
\text { signal } \\
\text { Hand Held } \\
\text { Counter for } \\
\text { count } \\
\text { vehicles. } \\
\text { Count } \\
\text { vehicles } \\
\text { using video }\end{array}$ \\
\hline
\end{tabular}




\begin{tabular}{|c|c|c|c|}
\hline & $\begin{array}{l}\text { vehicle } \\
\text { detection, } \\
\text { Inflatable } \\
\text { Road tube } \\
\text { counting, } \\
\text { Electric } \\
\text { sensor, } \\
\text { Magnetic } \\
\text { Sensor, } \\
\text { Acoustic } \\
\text { Detector, } \\
\text { Passive } \\
\text { Infrared and } \\
\text { Doppler and } \\
\text { Satellite } \\
\text { Microwave } \\
\text { Sensors. }\end{array}$ & & $\begin{array}{l}\text { vehicle } \\
\text { detection } \\
\text { WOT based } \\
\text { ticket sales, } \\
\text { movement } \\
\text { sensors, and } \\
\text { CCTV } \\
\text { cameras. }\end{array}$ \\
\hline Smart Parking & $\begin{array}{l}\text { road-surface } \\
\text { sensors } \\
\text { embedded in } \\
\text { the ground on } \\
\text { parking spots }\end{array}$ & $\begin{array}{l}\text { Local } \\
\text { People } \\
\text { business } \\
\text { civic and } \\
\text { company } \\
\text { groups } \\
\text { and } \\
\text { different } \\
\text { organizat } \\
\text { ions }\end{array}$ & $\begin{array}{l}\text { GPS data } \\
\text { from } \\
\text { drivers' } \\
\text { smartphone } \\
\text { s for } \\
\text { parking. }\end{array}$ \\
\hline $\begin{array}{l}\text { Smart energy } \\
\text { Management } \\
\text { (water, gas) }\end{array}$ & $\begin{array}{l}\text { Marinating } \\
\text { and managing } \\
\text { digital Meter } \\
\text { billing that } \\
\text { save paper, } \\
\text { water or gas } \\
\text { usage in real } \\
\text { time. }\end{array}$ & $\begin{array}{l}\text { Energy } \\
\text { Supplier } \\
\text { Organiza } \\
\text { tion and } \\
\text { Groups } \\
\text { Business } \\
\text { civics } \\
\text { and } \\
\text { organizat } \\
\text { ions }\end{array}$ & $\begin{array}{l}\text { WOT based } \\
\text { Smart } \\
\text { Metering } \\
\text { Smart water } \\
\text { managemen } \\
t \\
\text { Smart } \\
\text { electricity }\end{array}$ \\
\hline $\begin{array}{l}\text { Remote } \\
\text { Monitoring }\end{array}$ & $\begin{array}{l}\text { track and } \\
\text { control their } \\
\text { usage } \\
\text { remotely such } \\
\text { as water } \\
\text { leveling, } \\
\text { electricity, } \\
\text { parking } \\
\text { management, } \\
\text { Home } \\
\text { management }\end{array}$ & $\begin{array}{l}\text { Organiza } \\
\text { tion and } \\
\text { Groups } \\
\text { Business } \\
\text { civic and } \\
\text { organizat } \\
\text { ions }\end{array}$ & $\begin{array}{l}\text { Wot based } \\
\text { Parking, } \\
\text { Infrastructur } \\
e, \\
\text { Environmen } \\
t \text { waste } \\
\text { managemen } \\
t \text { and water } \\
\text { managemen } \\
t\end{array}$ \\
\hline Street Lighting & $\begin{array}{l}\text { Intelligent } \\
\text { street lighting } \\
\text { system that } \\
\text { connects } \\
\text { through an } \\
\text { intelligent } \\
\text { system. } \\
\text { WOT Based } \\
\text { Street } \\
\text { Lighting }\end{array}$ & $\begin{array}{l}\text { Local } \\
\text { People } \\
\text { and } \\
\text { communi } \\
\text { ty }\end{array}$ & $\begin{array}{l}\text { WOT based } \\
\text { smart } \\
\text { lighting } \\
\text { system, } \\
\text { WOT } \\
\text { enabled } \\
\text { events, } \\
\text { Transport } \\
\text { Schedule } \\
\text { check day } \\
\text { by day } \\
\text { routine and } \\
\text { year. }\end{array}$ \\
\hline Waste & Manage & compani & Wot based \\
\hline
\end{tabular}

\begin{tabular}{|c|c|c|c|}
\hline Management & $\begin{array}{l}\text { smartly waste } \\
\text { and water. } \\
\text { Manage sewer } \\
\text { system using } \\
\text { smart wot } \\
\text { devices and } \\
\text { sensors. flow } \\
\text { management } \\
\text { control by the } \\
\text { smart WOT } \\
\text { enabled } \\
\text { technology } \\
\text { with real time. }\end{array}$ & $\begin{array}{l}\text { es, local } \\
\text { authority } \\
\text { or } \\
\text { governan } \\
\text { ce and } \\
\text { environm } \\
\text { ental } \\
\text { groups } \\
\text { and } \\
\text { organizat } \\
\text { ions }\end{array}$ & $\begin{array}{l}\text { Water } \\
\text { leakage, } \\
\text { Smart } \\
\text { Sewer } \\
\text { System } \\
\text { Environmen } \\
\text { t problem } \\
\text { solve. }\end{array}$ \\
\hline Environment & $\begin{array}{l}\text { WOT- } \\
\text { enabled } \\
\text { devices used } \\
\text { for allow } \\
\text { tracking } \\
\text { parameters } \\
\text { critical for a } \\
\text { healthy } \\
\text { environment } \\
\text { of Smart } \\
\text { cities. }\end{array}$ & $\begin{array}{l}\text { Local } \\
\text { People } \\
\text { business } \\
\text { civic and } \\
\text { company } \\
\text { groups } \\
\text { and } \\
\text { different } \\
\text { organizat } \\
\text { ions }\end{array}$ & $\begin{array}{l}\text { Maintain } \\
\text { water } \\
\text { quality, } \\
\text { check no2 } \\
\text { level on air } \\
\text { and connect } \\
\text { them to a } \\
\text { cloud } \\
\text { managemen } \\
\text { t platform. } \\
\text { Air Quality } \\
\text { Measures } \\
\text { using WOT }\end{array}$ \\
\hline $\begin{array}{l}\text { Public Safety } \\
\text { and Security }\end{array}$ & $\begin{array}{l}\text { WOT-based } \\
\text { technologies } \\
\text { used real time } \\
\text { monitoring, } \\
\text { analytics, and } \\
\text { decision- } \\
\text { making for } \\
\text { system for fofy } \\
\text { public safety } \\
\text { and security. }\end{array}$ & $\begin{array}{l}\text { Local } \\
\text { People } \\
\text { business } \\
\text { civic and } \\
\text { company } \\
\text { groups } \\
\text { and } \\
\text { different } \\
\text { organizat } \\
\text { ions }\end{array}$ & $\begin{array}{l}\text { cameras } \\
\text { around } \\
\text { town } \\
\text { IP video } \\
\text { surveillance } \\
\text { system } \\
\text { emergency } \\
\text { signaling } \\
\text { ShotSpotter } \\
\text { It is a big } \\
\text { data tools } \\
\text { for protect } \\
\text { road crime. }\end{array}$ \\
\hline Smart Building & $\begin{array}{l}\text { WOT enabled } \\
\text { building } \\
\text { integrating } \\
\text { communicatio } \\
\text { ns and } \\
\text { building } \\
\text { control } \\
\text { systems }\end{array}$ & $\begin{array}{l}\text { Local } \\
\text { People } \\
\text { business } \\
\text { civic and } \\
\text { company } \\
\text { groups } \\
\text { and } \\
\text { different } \\
\text { organizat } \\
\text { ions }\end{array}$ & $\begin{array}{l}\text { Light } \\
\text { Control } \\
\text { System in } \\
\text { Building } \\
\text { Heating } \\
\text { Control } \\
\text { All Safety } \\
\text { \& Security } \\
\text { in Building. } \\
\text { All features } \\
\text { control and } \\
\text { analytics } \\
\text { using BIG } \\
\text { data and } \\
\text { WOT. }\end{array}$ \\
\hline Smart Education & $\begin{array}{l}\text { Provide a } \\
\text { WOT Enabled } \\
\text { online } \\
\text { Education }\end{array}$ & $\begin{array}{l}\text { educatio } \\
\text { nal } \\
\text { institutio } \\
\text { ns and } \\
\text { academic } \\
\text { communi }\end{array}$ & $\begin{array}{l}\text { WOT } \\
\text { Enabled } \\
\text { Classes and } \\
\text { Lectures } \\
\text { Massive } \\
\text { Open } \\
\end{array}$ \\
\hline
\end{tabular}




\begin{tabular}{|c|c|c|c|}
\hline & & $\begin{array}{l}\text { ty } \\
\text { local } \\
\text { authority } \\
\text { or } \\
\text { governan } \\
\text { ce } \\
\text { local } \\
\text { people } \\
\text { and } \\
\text { residents }\end{array}$ & $\begin{array}{l}\text { Online } \\
\text { Course } \\
\text { MCQ Type } \\
\text { WOT } \\
\text { enabled } \\
\text { Paper }\end{array}$ \\
\hline $\begin{array}{l}\text { Smart } \\
\text { Healthcare }\end{array}$ & $\begin{array}{l}\text { Provide a } \\
\text { WOT Enabled } \\
\text { Healthcare } \\
\text { Facilities }\end{array}$ & $\begin{array}{l}\text { local } \\
\text { authority } \\
\text { or } \\
\text { governan } \\
\text { ce } \\
\text { local } \\
\text { people } \\
\text { and } \\
\text { residents } \\
\text { environm } \\
\text { ental } \\
\text { groups } \\
\text { and } \\
\text { organizat } \\
\text { ions }\end{array}$ & $\begin{array}{l}\text { Wot } \\
\text { enabled } \\
\text { Smart } \\
\text { Hospitals } \\
\text { Home and } \\
\text { remote } \\
\text { heath care } \\
\text { Electronic } \\
\text { records } \\
\text { maintain in } \\
\text { Cloud } \\
\text { Storage. } \\
\text { Disease } \\
\text { control }\end{array}$ \\
\hline
\end{tabular}

\section{OVERVIEW OF WOT ENABLED SMART CITIES INTEGRATED BIG \\ DATA}

WOT enabled, Real-Time information System performs a vital role for running various services for smart cities (Fig 1)integrated Big Data platform. There are numerous applications used in real-time. Suppose, if the user wants to travel to different cities, he will first check which train, bus or airplane is better and secure for traveling. The user can check the time available for the train, bus so that he can find the best way for finding \& planning information about the trip is the real-time travel system. The public can easily find information about the availability of the next train, bus, and airplane. All this data retrieved by using Big Data Analytical tools such as $\mathrm{R}$ Programming, Python, etc. Another example of real-time is a parking system. Suppose if you are driving a car and looking for a parking or free room for your Vehicle. Real-time parking system could do wonders to locate the free space on the road. Using WOT, stakeholders can access extensive online services such as citizen services, business, and tourism services easily.

Today many of WOT enabled applications used. These applications providing a facility for various areas like public transportation like Intelligent road networks, connected cars , WOT enabled electricity services, water management, energy management, Smart education etc. WOT enabled health and social care services, public safety and security using Shot Spotter. These applications are more helpful in everyday life of citizens, and WOT enabled smart buildings, Education, etc. All that applications are used to implement Smart cities infrastructure like Wot enabled energy system, Wot enabled home, public safety and security, smart building designing, managing and controlling, WoT enabled health and wellness monitoring and storing large amount of data using Big Data interface, location-based applications such as GPS tracking system, mobile payments app etc.

\section{OVERVIEW OF WOT ENABLED SMART CITIES INTEGRATED BIG DATA}

Many metropolitan cities are using new Technology. These technologies include the Web of Things (WOT) connected devices. These devices are helpful to reduce costs, improve security and safety, better education, health sector, and promote public-private partnerships.

Smart city infrastructure is also using WOT enabled new technologies. It includes traffic optimization systems; water loss reduction systems; early-warning systems for emergency services; and waste removal system.

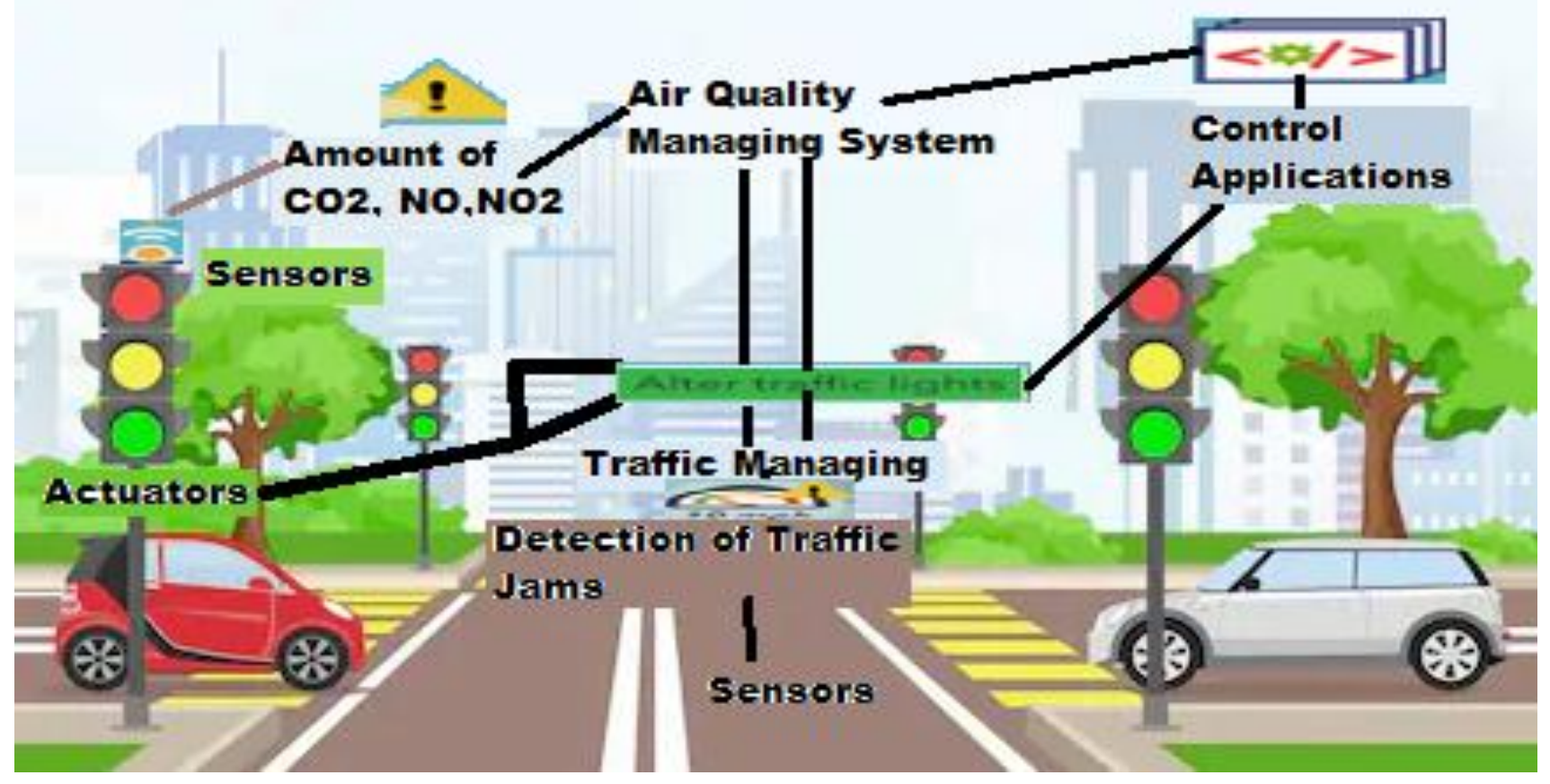

Fig 1: Overview of Public Transportation in Traffic Management 
The smart city infrastructure has the main problem of volume and velocity of Data. This problem can be resolved by using Big Data and Cloud Computing which is WOT enabled platform. These are new technologies which bring the resources and computation of data closer to the users and devices that need them. Smart city infrastructure is using WOT to Cloud [8]. Smart city infrastructure is sort of edge networks deployment scenario differs significantly from the standard enterprise deployment in several ways:

\section{Standalone edge networks \\ 2. Cloud-connected networks. \\ 3. API-connected networks.}

The end result for all that Web of Things is more helpful today for the creation of smart infrastructure.

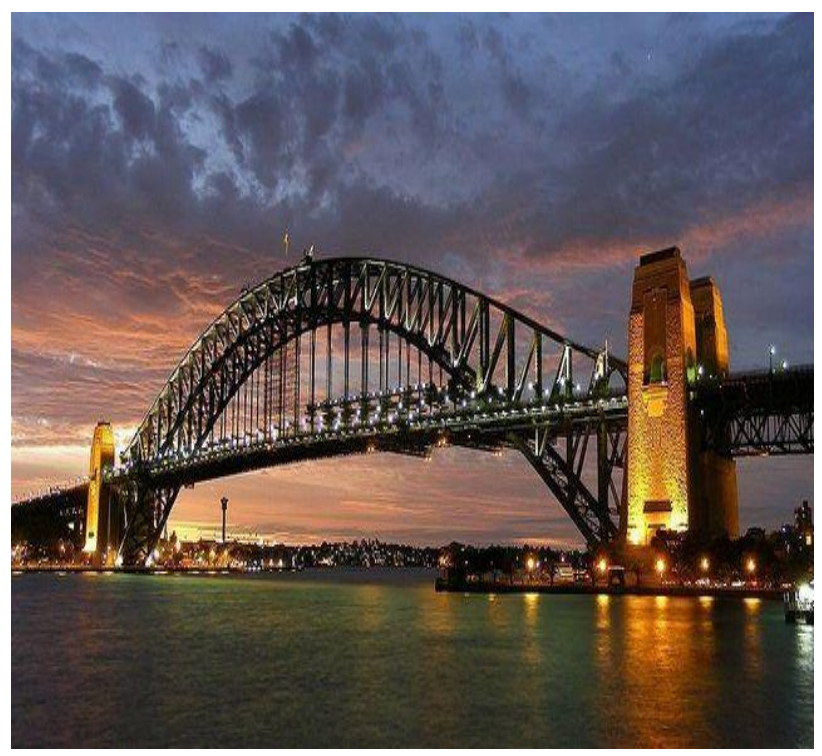

Fig 2: Smart Infrastructure

WOT is deployed to improve city applications and services. It helps to constructing the shape of building and also improve security of building. WoT integration Big Data also helps to improve services from a smart city outlook. The main problem or challenges faced in India for developing smart cities that approval of innovative WoT enabled services and application by the government. Many cities in India the internet speed is very slow so that is another problem for designing a smart city.

The creation of knowledge and information material is accessible anywhere through the network; it's not restricted but the main issue internet speed.

\section{ELEMENTS OF WOT FOR SMART CITIES INTEGRATION BIG DATA}

Elements of WOT for Smart Cities which are used to define structure blocks of a WOT enabled system and how they work? And How to collect, store and process data on the Web. There are some elements used:
1. Things: A "thing" is a sensor-based equipped system that gathers data or information which will be transferred via network and actuators. Actuators (It is a component of a machine used to poignant a mechanism or system example of this actuator is opening a valve. In simple terms, it is a "mover") that allow things to act (for example, to switch on or off the light, to open or close a door, to increase or decrease engine rotation speed and more). This concept includes refrigerators, street lamps, buildings, vehicles, production machinery, rehabilitation equipment, and everything else imaginable. Sensors are not in all cases, physically attached to the things: sensors may need to monitor, for example, what happens in the closest environment to a thing [3]

2. Gateways: Data goes from things to the cloud and vice versa through the gateways. A gateway provides connectivity between things and the cloud part of the WoT solution. It enables data preprocessing and filtering before moving it to the Internet (to reduce the volume of data for detailed processing and storing) and transmits control commands going from the Web of things. Things then execute commands using their actuators [9].

3. Data Lake: A data lake is used for storing the data which is generated by connecting devices in its natural format. Large data comes in batches or streams form. When the Data is needed for meaningful insights, it's extracted from a data lake and stored to a huge data warehouse as depicted in (see fig 3).

4. Data analytics: Data analysts can use data from the big data warehouse to find trends and gain actionable insights. When analyzed (and in many cases - visualized in schemes, diagrams, infographics) big data show, for example, the performance of devices, help identify inefficiencies and work out the ways to improve WoT system (make it more reliable, more customer-oriented) [10].

5. Big data warehouse: Filtered and preprocessed Data is needed for meaningful insight and is extracted from a data lake to a big data warehouse. A big data warehouse contains only cleaned, structured, and corresponding Data

6. Machine learning and the models ML generates: With machine learning, there is an opportunity to create more precise and more efficient models for control applications. Models are regularly updated (for example, once in a week or once in a month) based on the historical data accumulated in a big data warehouse. When the applicability and efficiency of new models are tested and approved by data analysts, new models are used by control applications. 


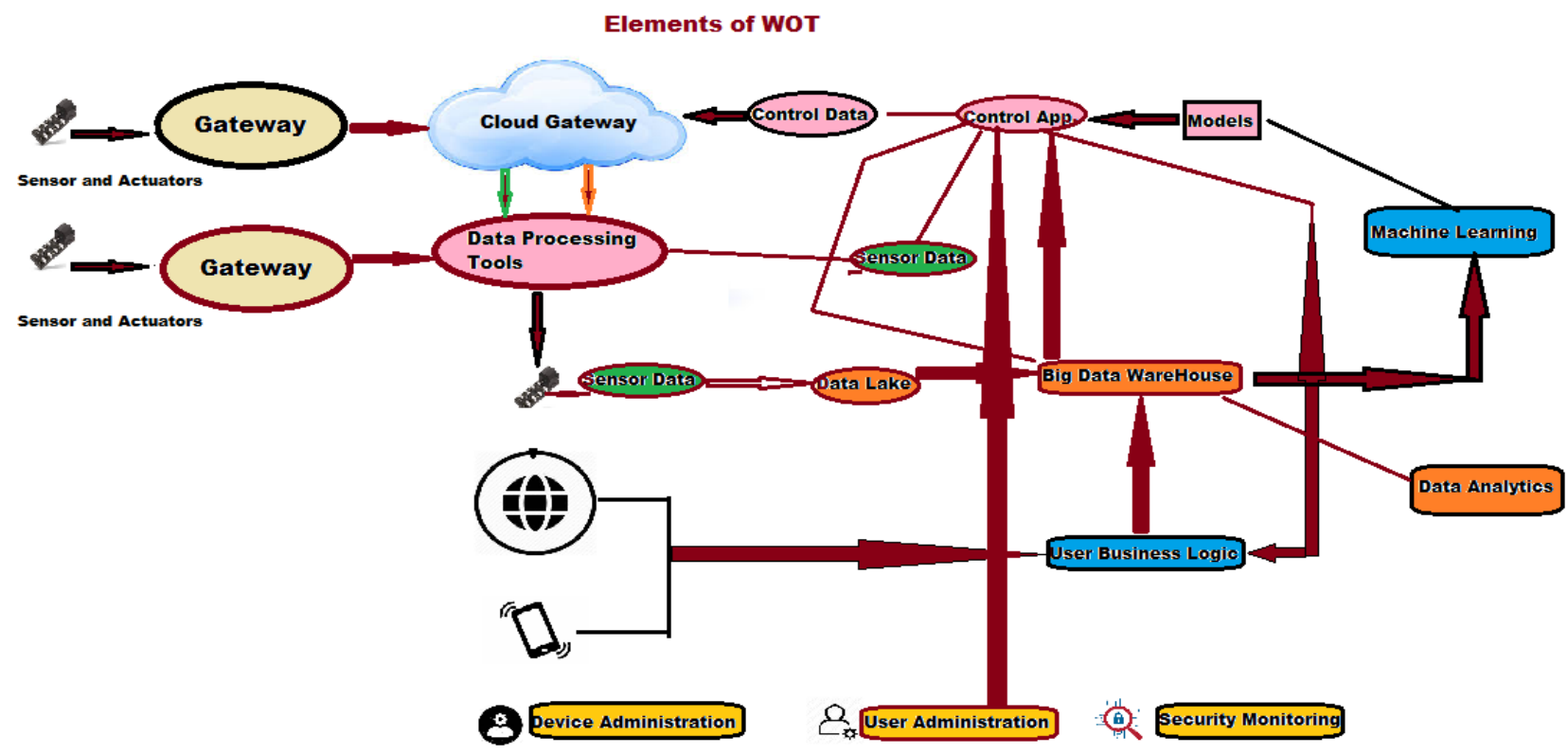

Fig 3: Elements of WOT enabled smart city integration Big Data

\section{WOT ENABLING TECHNOLOGY IN SMART CITIES}

\subsection{Wired Technology:}

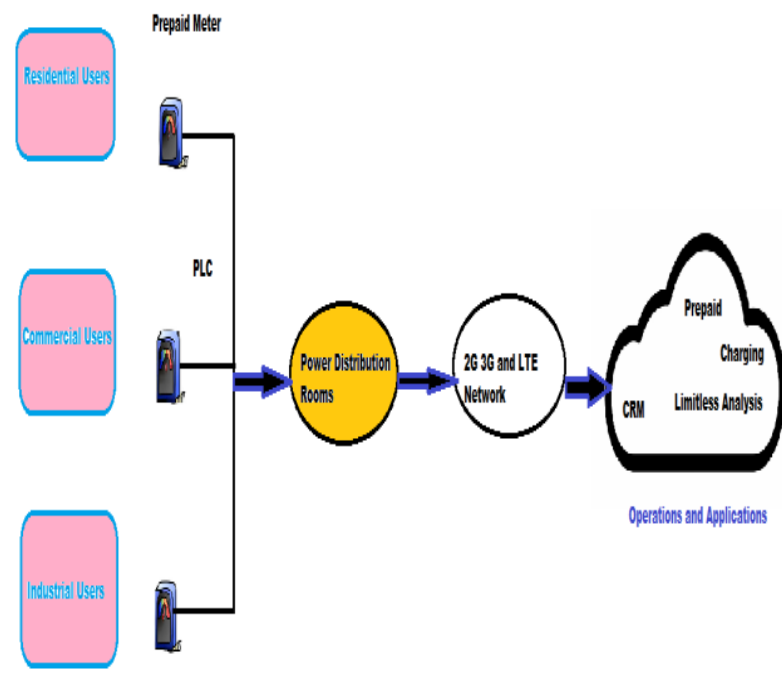

Fig 4: Smart metering using PLC

A smart city requires a strong wired communication for connecting devices and sensors using Cable. This wired communication is helpful to manage CCTV Camera, Digital Subscriber lines, Power cable, Electricity, Cable TV, etc.

Electricity meter and Power line communication are linked or connected with the wired connection. Airtel, Jio, and BSNL are using fiber optic cable for the broadband connection. These wired technologies are (fiber optical cable) providing better bandwidth and higher bit rate to the communication channel. PLC widely used for the electrical metering infrastructure.[4][5][6].

\subsection{Wireless Technology:}

For making a smart city, strong wireless communication is required for connecting devices and sensors. This wireless communication is helpful to manage crowdsensing, smart mobile devices, real-time tracking, road crime, and storing large data on the Web. Wireless communication within cities used for aggregations and access networks that can be either publicly or privately. The city can collect data from the devices and sensors link this Data from the building, traffic, and other applications. The data shares with the smart communication system, which is either wired or wireless. This Technology is helpful for sending and receiving valuable information from one place to other places such as health care, public safety, and security, traffic management, etc. and sensors used to connect devices as digitally. Wireless technologies day by day enhanced new standards and released information's. LTE is a new standard and released evolution, which managed by $4 \mathrm{G}$, as illustrated in Fig 4.2. The bit rates of $4 \mathrm{G}$ Technology is $600 \mathrm{Mbps}$ in cities. Now new technology $5 \mathrm{G}$ measured $1 \mathrm{Gbps}$ in cities (Fig 4.2). These technologies work on advanced techniques, like MIMO and ACM. $[4][5][6]$.

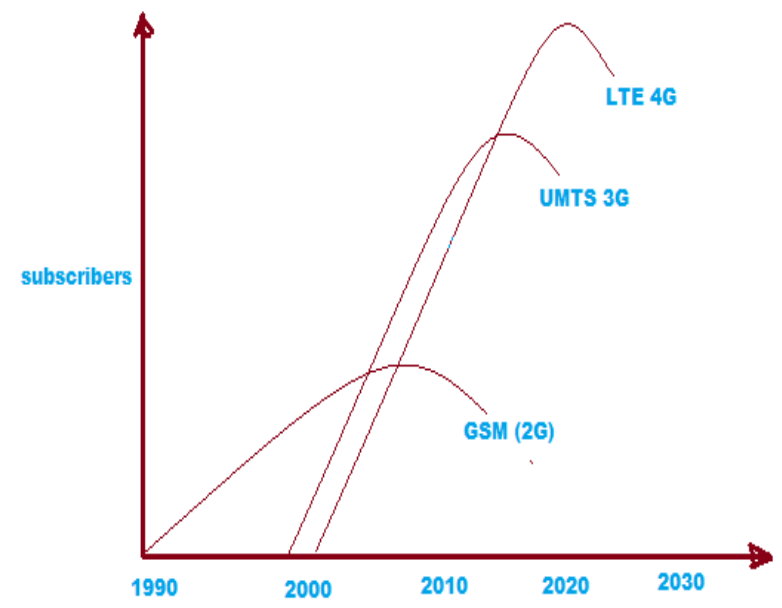

Fig 5: Life cycle of wireless technologies in the last three decades 


\section{WOT EXAMPLE/CASE STUDIES FOR SMART CITIES}

Let's check how WOT elements work together an example/ case studies of wot enabled lighting as a part of a smart home.

A big example of how WOT solution simultaneously contributes to user convenience and energy efficiency. There are some functions works for lighting on or off [3]

1. Sensors: It takes data from the environment, such as daylight, sounds, and people's movements. Lamps are an example of Sensors. It is equipped with the actuators to switch the light on and off.

2. Data Lake: It stores information or data which is coming from sensors.

3. Big data warehouse: It contains all the information's about the home. Like the energy costs and more.

4. User's control: It is a mobile app for smart lighting system. With this app users can see which lights are on and off and send commands to the control applications.

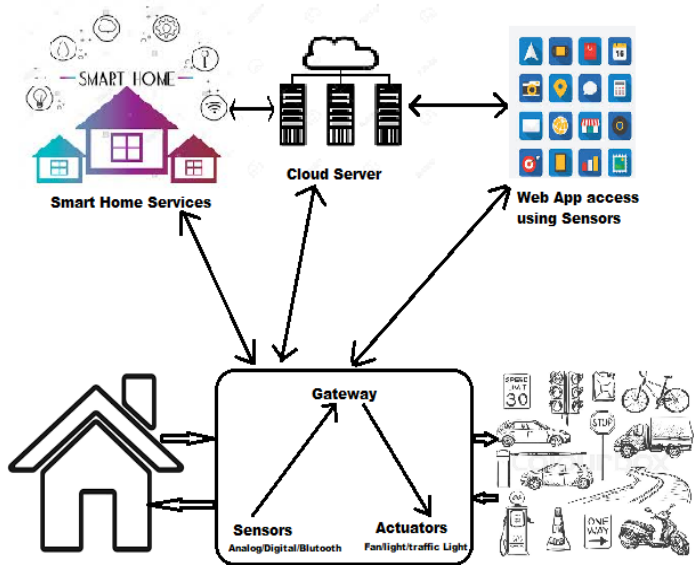

Fig 6: WOT enabled Lighting System for Smart Cities

5. Data analytics: It also helps in assessing the effectiveness of the WOT system and revealing problems in the way the system works.

6. Machine Learning: WOT enabled lighting can apply models generated by ML, for example, to recognize the patterns of home owners' behavior (leaving home at $8 \mathrm{am}$, coming back at $7 \mathrm{pm}$ ) and accordingly adjust the time when lights are switched on and off (for example, switch the lamps on 5 minutes before they will be needed).

\section{CONCLUSION}

WoT and Big Data helps us develop smart cities. It provides better applications and Data services for developing Smart Cities. Some bids such as WoT enabled lighting, road traffic, and Smart waste management are handled using WOT applications and large data analysis by Big Data Analytics.
Applying WoT Technologies leads to reduced costs for energy, optimized use of natural resources, safety, and security of cities, and provide a healthier environment [3]. Cities are becoming "smarter," and "intelligent" as governments, communities, and businesses rely on Technology to achieve goals and overcome changes. The smart city is about using new, rich sources of information concerning what is going on in the city and to remotely monitor and to use the remote control of various systems [2]. Municipal Corporation also used these applications and services to design functional and scalable smart city architecture. Well-designed, it will allow to reduce investments in WoT development and hasten the implementation of smart city solutions, still leaving space for expansion [3].

\section{REFERENCES}

[1] https://www.einfochips.com/blog/understanding-therole-of-smart-city-and-its- components-in-the-iot-era/

[2] https://www.omicsonline.org/open-access/smart-cityconcept-applications-and-services2167-0919117.php?aid=33684

[3] https://www.scnsoft.com/blog/iot-architecture-in-anutshell-and-how-it-works.

[4] http://www.intechopen.com/books/smart-citiestechnologies/

[5] https://www.rs-online.com/designspark/

[6] http://tec.gov.in/pdf/Studypaper/Enabling\%20Technologi es\%20for\%20Smart\%20Cities.pdf

[7] Harrison C, Donnelly IA (2011) A Theory of Smart Cities. Proceedings of the 55th Annual Meeting of the ISSS. Hull: International Society for the Systems Sciences.

[8] Schaffers H, Komninos N, Pallot M, Trousse B, Nilsson M, et al. (2011) Smart Cities and the Future Internet: Towards Cooperation Frameworks for Open Innovation, Lecture Notes in Computer Science.

[9] Viljanen K, Poikola A, Koponen P (2012) Information navigation in the city. The City of Helsinki: Forum Virium Helsinki and the Fireball project.

[10] Cimmino A, Pecorella T, Fantacci R, Granelli F, Rahman T, et al. (2013) The Role of Small Cell Technology in Future Smart City. Transactions on Emerging Telecommunications Technologies 25: 11-20.

[11] Hao L, Lei X, Yan Z, ChunLi Y (2012) The application and implementation research of smart city in China System Science and Engineering (ICSSE), Dalian, Liaoning, China.

[12] Zheng J, Jamalipour A (2009) Wireless Sensor Network s: A Networking Perspective. New Jersey: John Wiley \& Sons.

[13] https://www.sciencedirect.com/science/article/abs/pii/S2 210670717313379?via\%3Dihub 